\title{
Using Digital Media in Marketing when Presenting the Czech Republic's National Parks
}

\author{
Josef ŠTEMBERK, Petra MAREŠOVÁ \\ University of Hradec Králové, Hradec Králové, Czech Republic \\ \{josef.stemberk, petra.maresova\}@uhk.cz
}

\begin{abstract}
This paper analyses the area of modern, dynamically developing marketing tools in the field of tourism, using the example of national parks in terms of visitors' activity. Websites and social networks are currently an integral part of promoting process of each organisation. These include new tools, widely used by the majority of tourists - visitors. Their motivation is planning a future visit or they just watch the current events in a given location. Digital media represents a very pleasant, ubiquitous and accessible way for all interested parties. The aim of the paper is to evaluate the utilisation and the quality of provided information and also the way of Internet communication between the national parks in the Czech Republic. A quantitative method was chosen for the analysis as it's the most suitable method for the evaluating user activity. As an example study, the websites of all four Czech Republic national parks were chosen and their use of selected social networks. The paper describes the individual aspects of website structure and the potential of use is assessed.
\end{abstract}

Keywords: Websites Analysis, National Parks, Czech Republic

\section{$1 \quad$ Introduction}

Tourism is defined by the United Nations as the activity of people travelling to and also staying in places outside their usual environment for less than a year, in order to spend their free time, business and other non-business activities for which they are rewarded from the visited site [9].

Tourism is one of the largest and most dynamic economic sectors. It's an important and significant part of the external economy in many developed and developing countries throughout the world [10]. The high rate of tourism development affects different economic segments. In this sense, tourism is mainly understood to be a separate area of the national economy. Tourism as such, significantly affects other development areas, the most important of these undoubtedly include GDP creation, balance of payments contribution, state budget revenues, as well as having a significant effect on regional budget revenues and beneficially affecting the investment activity of other entities [8]. 
Tourism is inherently linked to marketing and marketing tools to obtain support for the given tourist sites.

According to Kotler [4], marketing mix is "a set of tactical marketing tools that a company uses to adjust the supply for target markets." A marketing mix includes everything a company can do to influence demand for its product." The concept of a marketing mix was dealt with by e.g. [2, 3]. Bachmann [1] states that: "Marketing has many forms and areas of use today. It has traditionally been associated with the business sector, its expansion into the non-profit sector in the 1960s and 1970s. In the 1990 s, the Internet phenomenon began to develop. Society is changing and the Internet is becoming a common way of life. Marketing naturally follows this fact and comes into its online form."

This paper analyses the segments supporting tourism development, specifically in the context of today's society well-established websites and selected social networks using the example of Czech national parks. Specific structures and related orientation for visitors [5-7], up-to-dateness, visual structure and other aspects will be compared. Given that all Czech national parks are situated on the national borders, so there are neighbours over the border to the adjacent national park - the so-called Transboundary Parks. The aspect of digital media inter-connection will also be assessed.

The issue of assessing the significance of social networks for the impact of tourist activity in the region and the related determination of the tourist potential in the area has always been a difficult task to research. The study of this paradigm began towards the end of the 20th century with the massive onset of information technologies and their approximation, adaptation to complete establishment in all society social groups. The aim of this paper is to analyse a certain part of the marketing, i.e. the current Internet tools - specifically the websites and selected social networks belonging to the Czech national parks as one part of the marketing mix for addressing and informing visitors.

\section{Methods}

This work uses the method of quantitative comparison of individual Czech national parks websites - regarding structure, quality, information and other characteristics.

According to Disman, [3], quantitative methods are best suited to investigating simple and measurable traits or combinations thereof. The analysis of all four Czech national park websites, visual representations, up-to-dateness, language versions, types of posts, tourism promotion and creating a separate application are compared, as well as using the following selected social networks such as Instagram, Facebook (number of friends, number of followers, response rate and rating) and twitter (tweets, following, followers and connecting to this network). 


\section{Results}

\subsection{Comparison of the use of websites and social networking}

With the advent of new marketing tools, all institutions, irrespective of whether they're private or public, including the Czech national parks, started to create their first websites that have been improved and edited for their users over the years. As part of this paper, a comparison of individual Czech National Park websites as of 28.10.2017 has been carried out - see Table 1 below.

From the analysis carried out, in terms of structure, visual style, search intensity, language versions and other aspects of Czech national parks individual websites, the following applies:

Šumava National Park has a visually appealing website that are organised logically for the visitor and well-sorted individual icons and other related components, however, the information contained on this website is extensive. In case of a quick search in hectic times, it's necessary to use the search engine on this website. However currently, the available information suggests generalisation, clarification and updating existing websites.

In terms of clarity and visual aspect, the best website is the Krkonoše National Park, which appeals to be modern, clear and in very interactive manner, in the sense of up-to-date and includes the possibility of response. A very interesting attraction for users is the absolutely identical website structure for two neighbouring border national parks and the website visitor chooses right from the start whether they would like to see the Polish Karkonoszki park narodowy or the Krkonoše (Ore Mountains) National Park. Both parks have the same logo - the only difference being, that the inscription that is part of the logo is always in the national language. Other up-to-date news featured in this park is the built-in National Park application for Smartphones, which demonstrates its connection and approach to potential visitors through a new marketing tool, namely social networks. A huge welcoming moment for Facebook social network visitors or users is the fact that the response is within 24 hours on this type of media, such a rapid response from all four national parks isn't recorded for any others.

The České Švýcarsko (Czech Switzerland) National Park, with its neighbouring German partner, the Sächsische Schweiz National Park, has a similar graphic design for the website, which is very pleasant for visitors of this border region. Websites have a well-designed structure for good visitor orientation in the virtual world. From the viewpoint of tourist information, individual tourist destinations or attractions, the National Park website contains the absolute minimum, especially because regional tourist destination management is in operation in this region, i.e. the local benefit company of Czech Switzerland, o.p.s. It manages all tourist information and offers for visitors and the National Park is one of the stakeholders. Therefore, all tourist destinations are promoted on the company's website. Destination management has also created its own application for this national park's visitors.

The Podyji National Park's website is visually stark compared to the sites mentioned above and it's less attractive in regard to visual comparison. However, this 
park's website is clear and simple to navigate and it also provides a quick search on the information you need.(Table 1)

Table 1 Comparison of National Park's website

\begin{tabular}{|c|c|c|c|c|}
\hline & $\begin{array}{c}\text { Šumava National } \\
\text { Park }\end{array}$ & $\begin{array}{c}\text { Krkonoše } \\
\text { National Park }\end{array}$ & $\begin{array}{c}\text { Bohemian } \\
\text { Switzerland } \\
\text { National Park } \\
\end{array}$ & $\begin{array}{c}\text { Podyjí } \\
\text { National } \\
\text { Park } \\
\end{array}$ \\
\hline Websites & yes & yes & yes & yes \\
\hline Clarity & $\begin{array}{l}\text { medium } \\
\text { huge - }\end{array}$ & yes & $\begin{array}{l}\text { medium } \\
\text { big - }\end{array}$ & yes \\
\hline $\begin{array}{l}\text { Scope of } \\
\text { information }\end{array}$ & $\begin{array}{l}\text { complicated for } \\
\text { orientation }\end{array}$ & medium & $\begin{array}{l}\text { complicated for } \\
\text { orientation }\end{array}$ & medium \\
\hline $\begin{array}{l}\text { Connected with the } \\
\text { transboundary }\end{array}$ & & & & \\
\hline national park & no & yes & no & no \\
\hline English translation & yes & yes & yes & yes \\
\hline $\begin{array}{l}\text { Other language } \\
\text { translations }\end{array}$ & German & Polish & German & $\begin{array}{l}\text { German } \\
\text { current, }\end{array}$ \\
\hline Typs of articles & $\begin{array}{l}\text { current, } \\
\text { interesting, } \\
\text { adequate and } \\
\text { up-to-date, } \\
\text { attractive for } \\
\text { visitors }\end{array}$ & $\begin{array}{c}\text { current, } \\
\text { interesting, } \\
\text { adequate and } \\
\text { up-to-date, } \\
\text { attractive for } \\
\text { visitors }\end{array}$ & $\begin{array}{c}\text { current, } \\
\text { interesting, } \\
\text { adequate and } \\
\text { up-to-date, } \\
\text { attractive for } \\
\text { visitors }\end{array}$ & $\begin{array}{c}\text { interesting, } \\
\text { adequate } \\
\text { and up-to- } \\
\text { date, } \\
\text { attractive } \\
\text { for visitors }\end{array}$ \\
\hline Currents & yes & yes & yes & yes \\
\hline & & & no - job of est. & \\
\hline PR of tourism & & & Public Service & \\
\hline attractions & yes & yes & Company & yes \\
\hline Visual shape & $\begin{array}{l}\text { visually } \\
\text { impressive, } \\
\text { above all the } \\
\text { headings, many } \\
\text { subfolders and } \\
\text { recommendable } \\
\text { via search for } \\
\text { findings and } \\
\text { quick response }\end{array}$ & $\begin{array}{l}\text { clear, easy for } \\
\text { orientation and } \\
\text { serching, good } \\
\text { designation and } \\
\text { naming }\end{array}$ & $\begin{array}{l}\text { more difficult } \\
\text { for searching - } \\
\text { less } \\
\text { components } \\
\text { and many } \\
\text { subfolders, } \\
\text { recommendable } \\
\text { via search }\end{array}$ & $\begin{array}{l}\text { clear, easy } \\
\text { for } \\
\text { orientation, } \\
\text { visually } \\
\text { less } \\
\text { impressive } \\
\text { a. } \\
\text { attractive }\end{array}$ \\
\hline Own App & no & $\begin{array}{l}\text { yes (it is their } \\
\text { own product) }\end{array}$ & $\begin{array}{c}\text { yes (product of } \\
\text { the Public } \\
\text { Service Co.) }\end{array}$ & no \\
\hline Facebook & yes & yes & yes & yes \\
\hline $\begin{array}{l}\text { Number of friends } \\
(28.10 .2017)\end{array}$ & 23936 & 18084 & 9489 & 2790 \\
\hline Number of viewers & 23445 & 17796 & 9426 & 2769 \\
\hline
\end{tabular}




\begin{tabular}{|c|c|c|c|c|}
\hline \multicolumn{5}{|l|}{$(28.10 .2017)$} \\
\hline Quick reply & neutral & $\begin{array}{l}\text { yes - at latest in } \\
\text { one day }\end{array}$ & neutral & neutral \\
\hline $\begin{array}{l}\text { Evaluation } \\
(28.10 .2017)\end{array}$ & $\begin{array}{l}4,8(47 \\
\text { reviews) }\end{array}$ & $\begin{array}{c}4,2(68 \\
\text { reviews })\end{array}$ & $\begin{array}{l}4,9(227 \\
\text { reviews) }\end{array}$ & $\begin{array}{l}4,7(188 \\
\text { reviews) }\end{array}$ \\
\hline Currents & yes & yes & yes & yes \\
\hline Instagram & yes & yes & yes & yes \\
\hline Twitter & yes & yes & yes & yes \\
\hline $\begin{array}{l}\text { tweets } \\
(28.10 .2017)\end{array}$ & 192 & 1528 & 968 & 279 \\
\hline $\begin{array}{l}\text { viewing } \\
(28.10 .2017)\end{array}$ & 0 & 279 & 27 & 283 \\
\hline $\begin{array}{l}\text { viewers } \\
(28.10 .2017)\end{array}$ & 193 & 794 & 406 & 193 \\
\hline joined in & August 2009 & June 2015 & October 2010 & $\begin{array}{l}\text { December } \\
2011\end{array}$ \\
\hline
\end{tabular}

If Facebook social network is compared, especially from the viewpoint of the possible quantified number of friends and the number of followers, it can be stated that it corresponds to the individual sizes of the national parks. So the most extensive Šumava National Park has the largest number of friends and followers, followed by the Krkonoše National Park. The smallest number belongs to Podyjí, the Czech Republic's smallest national park. At the same time, it has to be mentioned that the response to the reactions, i.e. the actual response to individual stimuli, is the absolute best with the Krkonoše National Park, which responds within 24 hours. Such service isn't offered by any other national park

In terms of Facebook evaluation, all national parks are comparable, the lowest imaginary position surprisingly belongs to the Krkonoše National Park, which is surprising with regard to structure and constant updating. Instagram and Twitter are both used by all Czech national parks. However, links to these particular social networks aren't listed on their homepage. Only the Podyji National Park has a link for the Twitter application on its website.

From the point of view of the comparison of Twitter's social network, it's the most successful in the number of tweets and watching the Krkonoše National Park, even though it was the last to join the network. It's followed by the České Švýcarsko National Park. The worst statistic in terms of tweets and following is surprisingly reported by the Šumava National Park, even though it was first to join the network in August 2009.

\section{Conclusion}

The Internet and other social networks are the more current marketing tools used to support tourism and as well as for current awareness of events or news. The Czech national parks approach this new media individually. The significance of these media 
outlets is to share different insights, news or warnings and to share your own opinions. For individual administrations of these public institutions, this is an interesting feedback in relation to the further direction and possible development of the given areas.

According to our opinion, the pages on the Krkonoše National Park websites are among the most pleasant and most user-friendly. Importantly, the fact that they unite with their cross-border neighbour, the Polish National Park and are therefore very user-friendly for quick orientation. The remaining national parks have the same geographic location and so they're destined for a similar possibility for this kind of social media, which would certainly be welcomed by the users. Language versions are unified regarding English. The other language version is based on the reality with which state and therefore language they adjoin across the state border, which is logical and natural.

The most significant difference in the České Švýcarsko National Park Administration's website is the absence of a description for tourist attractions that the company o.p.s. presents as a regional manager who supports this activity. Facebook, Instagram as well as Twitter are used by all Czech national parks in basic form.

It's also clear that the Internet and social networks have become an obligatory part of the national parks marketing tools, which is firmly established in today's information technology society. Nowadays, they're considered to be an indispensable part of promotion even in the case of large-scale protected territories dominated by national parks. Their development and future adjustments are entirely natural, according to the further development of these media and public pressure to make the pages clear and accurate.

Acknowledgements. The paper was created with the support of the internal specific research titled "Evaluation of Investments in the Industry 4.0 Concept" of the Faculty of Informatics and Management of the UHK.

\section{References}

1. Bachmann, P.: On-line marketing v neziskové organizaci: Analýza webových stránek organizací Královéhradeckého kraje. Sociální studia. Katedra sociologie FSS MU, 3/2011. S. 97-110. (2011)

2. Borden, N.H.: The Concept of the Marketing Mix, Journal of Advertising Research, 1964, pp 2-7 and reprinted in: Baker, M.J. (ed), Marketing: Critical Perspectives on Business and Management, Vol. 5, Routledge, pp 3-4 (2001)

3. Disman, M.: Jak se vyrábí sociologická znalost. Praha: Karolinum. (2011)

4. Kotler, P., Wong, V., Saunders, J., Armstrong, G.: Moderní marketing. Grada Publishing, (2007).

5. Štemberk, J., Štemberková, R., Marešová, P., Kuča, K.: Knowledge and Personal Managment In Public Administration. In: Psychology and psychiatry, sociology and healthcare, education (SGEM 2015). Sofia. pp. 509-517. 
6. Štemberk, J., Štemberková, R., Marešová, P., Kuča, K.: Organizational Structure - A Case Study On The National Parks In The Czech Republic. In: Psychology and psychiatry, sociology and healthcare, education (SGEM 2015). Sofia. 2015, pp. 629-637. (2015).

7. Štemberk, J., Štemberková, R., Marešová, P., Kuča: K. Analysis of Efficiency of Personnel Management of National Parks - „Best Practice”- Comparison on the National Parks Šumava and Bayerischer Wald as a case study. In: 2016,

8. The Statistic Portal. (2017). https://www.statista.com/statistics/233223/travel-and-tourism-total-economic-contribution-worldwide/, last accessed 2017/10/26

9. World Tourism Organization UNWTO (2017). http://www2.unwto.org/content/about-us-5, last accessed 2017/10/26

10. World Trade

organization.

(2017).

https://www.wto.org/english/tratop_e/serv_e/tourism_e/tourism_e.htm, last accessed $2017 / 10 / 26$ 